\title{
The Restructuring Process of the University of Guadalajara: Benefits After 25 Years of the Jalisco University Network
}

\author{
Rosalba Madrigal Torres \\ University of Guadalajara \\ Berta Ermila Madrigal Torres \\ University of Guadalajara \\ Natalia Nayeli Garibay Madrigal
University of Guadalajara
}

\begin{abstract}
The restructuring of the University of Guadalajara of schools and faculties by thematic and regional University Centers make up the University Network. Our objective of this work is to analyze and identify the contributions of the University Network within the framework of its social responsibility, through teaching, the extension of services, as well as cultural production and dissemination, its impact on regional development. The decentralization and regionalization of administrative and academic functions was complex. The link with social responsibility through teaching was aimed at solving problems in the communities. The academics designed research projects linked to the actions of the City Councils, the business sector and social groups. Results: the Jalisco University Network, due to the educational, economic and cultural impact, has fostered the permanence of young people in their communities, in addition to generating internal and external mobility of students and teachers; greater interaction of the university with the different social and productive sectors. Higher education functions as an integrating instrument in the regional development of the State of Jalisco.
\end{abstract}

Keywords: university network, university centers, University of Guadalajara, academic reform

\section{INTRODUCTION}

The effort to decentralize the University's higher secondary education services to the regions of the State of Jalisco began in 1975, so that students would remain in their places of origin. Our objective is to identify the contributions of the University Network in regional development through teaching, extension of services, as well as cultural production and diffusion.

The term network refers to a set of relationships between various organizational units around an objective. The units are autonomous and dependent on the whole through rules based on decentralization, participation and coordination (Grandori and Giuseppe, 1995); the functioning consists of the freedom of its units to make decisions and their interaction by sharing the same interests. 
In the case of the University Network, it is the set of entities that make up the University of Guadalajara; integrated by its Governing Bodies, University Centers, the Higher Secondary Education System, the Virtual University System and dependencies of the General Administration, (UdeG, 2018).

Decentralization made it possible to bring education to all regions of the state of Jalisco. The problem of the University Network is focused on the teacher-student relationship. Teaching is more complex. It represents a challenge to today's students because they have access to other types of information. It is essential to innovate in the functions of teaching and research with an interdisciplinary approach according to public policies related social inclusion and care of the environment.

During the 1995-1996 school year, the University of Guadalajara enrolled 138,679 students. The University Network has contributed to the social welfare of Jalisco families who have benefited, so that their children do not need to migrate to the metropolitan area to continue their studies. In the last decades the enrollment increased $55.39 \%$, in the cycle (2020-2021) the student population is 310,845 .

Currently, the University of Guadalajara contributes to the development of public policies in higher education for the achievement of the Sustainable Development Goals of the United Nations by chairing the West Central Regional Council and being a member of the National Council of the National Association of Universities and Institutions of Higher Education (Asociación Nacional de Universidades e Instituciones de Educación Superior).

\section{METHODOLOGY}

The first part of the paper approaches, from a theoretical perspective with an interdisciplinary approach, the concept of university network, for the analysis of public policies, in order to know the dimension of the institution. The data supporting the analysis were obtained from institutional activity reports and secondary sources; content analysis was chosen for the organization of the data, the elaboration of the matrix of indicators established by the social sciences in the case study to present qualitative information, and the analysis of the social sciences in the case study to present qualitative information.

\section{DEVELOPMENT}

Jalisco is one of Mexico's 31 states and is located in the west-central part of the country. The State Government in 1996 initiated a new administrative regionalization that concluded two years later, to promote the progress of the entity, grouped the 125 municipalities in 12 regions: North, High North, High South, Ciénega, Southeast, South, Sierra de Amula, South Coast, North Coast, Western Sierra, Valleys and a Sub-region Center Conurbana.

The Planning Law for the State of Jalisco and its Municipalities establishes that planning for the development of the state is guided by the principle of regionalization as a strategy aimed at balanced development, establishing the priorities to be addressed in each of the regions.

During the period 1989-1995, national education policies instructed institutions of higher education to make changes to improve their academic and administrative structure, to have performance indicators and linkages. It is important to reflect on some historical dates that give support to the transcendental changes of our Alma Mater.

The emblematic Ibero-American Library of the University of Guadalajara, in colonial times was the campus of the Colegio de Santo Tomás until 1784, when the prosecutor of the Court, Maldonado, gave the property to Fray Antonio Alcalde y Barriga, bishop of Guadalajara, benefactor of welfare works and promoter of higher education. The bishop took up the project of creating a university (Acosta Rico, 2016). Thanks to the intervention of the bishop and the ideals of characters of that time, on November 3, 1792, the Royal University of Guadalajara was inaugurated.

After the War of Independence between 1826 and 1860 the University suffered closures and ruptures, as a consequence of the struggles between conservative and liberal governments, originating name changes (Real Ledezma, 2015). The reopening in 1925, allowed the ideals of the Mexican Revolution and to become a public, secular, free institution of higher education for the promotion of social development and 
democracy. José Guadalupe Zuno Hernández, as governor of the State of Jalisco, promoted the founding of the University, and Enrique Díaz de León, ideologist and first rector of the University, was the first rector of the University.

On September 2, 1989, the General University Council approved the document "Bases for the discussion of the Reform of the University of Guadalajara", which proposes the decentralization of the services and functions of the institution.

Therefore, in 1991, when the General University Council approved the University of Guadalajara's Academic Personnel Statute and the Regulations for Admission, Retention and Promotion of Academic Personnel, the basis for the promotion of employees according to their skills and knowledge was established. Consequently, in 2003 the Pension, Retirement and Social Benefits System of the University of Guadalajara came into effect, establishing the mandatory requirement of 30 years of service and 65 years of age.

In 1991-1992, the consultation between the university community and society was carried out in the Institutional Development Plan: A Vision for the Future, which defined four lines of development:

1. Democratic access to education and academic excellence;

2. Decentralization and regionalization;

3. Linkage with the social and productive sectors;

4. Academic and administrative flexibility.

In 1994, the new Organic Law of the University of Guadalajara entered into force. The departmental model was adopted. The credit system replaced the old structure of schools and faculties. The structure of the Departments is grouped into Divisions by area of knowledge. The Division Director presides over the Divisional Council, which is responsible for promoting the processes for the creation, modification or suppression of curricular plans and programs; proposing annual operating programs for research and technological development; promoting linkage actions with the public, private and social sectors; and formulating institutional programs in which academic, administrative and student personnel participate.

The University Network is made up of 15 University Centers: 6 metropolitan thematic centers and 9 regional centers; 2 university systems, the Virtual University and the Higher Secondary Education System.

TABLE 1

\section{UNIVERSITY OF GUADALAJARA - UNIVERSITY NETWORK}

\begin{tabular}{|c|c|c|c|c|c|}
\hline \multirow[b]{2}{*}{ Themed University Centers } & \multirow[b]{2}{*}{$\begin{array}{c}\text { Year of } \\
\text { establishment }\end{array}$} & \multicolumn{2}{|c|}{ Students } & \multicolumn{2}{|c|}{ Professors } \\
\hline & & Males & Females & $\begin{array}{c}\mathrm{TCP} \\
\mathrm{M}\end{array}$ & $\begin{array}{c}\text { TCP } \\
\mathrm{F}\end{array}$ \\
\hline CUAAD - Art, Architecture and Design & 1994 & 3,650 & 4,428 & 122 & 83 \\
\hline CUCBA - Biological and Agricultural Sciences & 1994 & 3,448 & 3762 & 183 & 127 \\
\hline CUCEA - Economic-Administrative Sciences & 1994 & 9,689 & 12,057 & 273 & 165 \\
\hline CUCEI - Exact and Engineering Sciences & 1994 & 12,374 & 4,900 & 373 & 177 \\
\hline CUCS - Health Sciences & 1994 & 6,467 & 11,409 & 270 & 266 \\
\hline CUCSH - Social Sciences and Humanities & 1994 & 5,475 & 7,468 & 310 & 310 \\
\hline Tlajomulco Campus & 2020 & 255 & 246 & - & - \\
\hline Total & & 41,358 & 44,270 & 1,531 & 1,128 \\
\hline \multicolumn{6}{|l|}{ Systems } \\
\hline Higher Secondary Education System & 1994 & 75,687 & 93,915 & 647 & 537 \\
\hline Virtual University System & 2005 & 1,987 & 2,365 & 38 & 61 \\
\hline
\end{tabular}




\begin{tabular}{|l|l|l|l|l|l|}
\hline Regional University Centers & \multicolumn{5}{l|}{} \\
\hline CUALTOS - Tepatitlán de Morelos & 1994 & 1,520 & 2,607 & 57 & 46 \\
\hline CUCIÉNEGA - Ocotlán & 1994 & 2,865 & 3,356 & 98 & 69 \\
\hline CUCOSTA - Puerto Vallarta & 1994 & 3,300 & 3,751 & 81 & 61 \\
\hline CUCSUR - Autlán de Navarro & 1994 & 2,365 & 2,216 & 106 & 57 \\
\hline CULAGOS - Lagos de Moreno & 2004 & 1,555 & 1,598 & 56 & 34 \\
\hline CUNORTE - Colotlán & 2000 & 1,731 & 2,349 & 40 & 34 \\
\hline CUSUR - Ciudad Guzmán & 1994 & 2,857 & 4,572 & 81 & 60 \\
\hline CUTONALÁ - Tonalá & 2012 & 3,640 & 3,640 & 88 & 79 \\
\hline CUVALLES - Ameca & 2000 & 1,898 & 2,495 & 80 & 53 \\
\hline Total & & 21,731 & 26,584 & 687 & 493 \\
\hline
\end{tabular}

Source: CGPE-UdeG. Ciclo 2020-2021.

In 2000, the North and Los Valles campuses were created, changed to University Centers in 2004, and the Los Lagos University Center was created. In 2005, the Virtual University System was established. In 2012, the University Center of Tonala and the University System for the Elderly were created, as can be seen in the table above, before the creation of the University Network, the University already had a presence within the State (see Table 1).

In 2020 the University of Guadalajara, the Government of Jalisco and the City Council of Tlajomulco de Zúñiga agreed on the gradual integration of the Polytechnic University of the Metropolitan Area of Guadalajara (UPZMG) to the UdeG, as the University Center of Tlajomulco, without affecting students or workers; it was created by decree No. 20449 by the Congress of the State of Jalisco, on January 22, 2004. UPZMG students will have the opportunity to revalidate subjects and conclude their studies at the UdeG. The university has 99 professors, of which 9 are full-time professors (PTC) and 90 are subject professors (PA). 30\% are women and 70\% are men (UPZMG, 2018, p.20).

The distribution of the enrollment period (2020-2021) of the University Network of Jalisco University of Guadalajara of 310,845 students: $55.49 \%$ in higher secondary education and 55.49\% in higher education. The female presence is $54.52 \%$ compared to $43.11 \%$ male. Meanwhile, $63 \%$ of the enrollment is located in the metropolitan area and $37 \%$ in the regional area. The Higher Secondary Education System (SEMS) serves 109 of the 125 municipalities in the state $(87.20 \%)$ (see Table 1). The educational, cultural and economic impact of the University Network has contributed to regional development.

The teaching staff of the University Network is comprised of 16,884 members of the academic staff. $57.24 \%$ are men and $42.76 \%$ are women. Of these percentages, $18.54 \%$ are men and $13.14 \%$ are women, i.e., this is the segment of academics with the best working conditions and greater seniority; $24.67 \%$ work in the Thematic Centers and 7.02\% in the Regional University Centers. There is a segment of academics whose work relationship is by course, 9,097 academics: $53.88 \% 30.70$ men and $23.18 \%$ women; $59.87 \%$ work in the SEMS, representing an area of opportunities to work on (CGPE, 2020).

The University Network has been able to provide educational opportunities for 137,000 students in 1994 to 310,845 students in 2020 . From 66 bachelor's degrees, there are currently 228 and 163 postgraduate degrees; from 1,800 classrooms, there are now more than 4,300 throughout Jalisco. Social, scientific and technological innovation stands out as one of the social contributions of universities derived from the research of projects that provide solutions to social needs, (Noticiasncc, 2019).

One of the main positive results is the permanence of young people in their communities, the University Network within the state of Jalisco, serves 116,013 students $(41.39 \%)$; internal and external mobility of students and professors; greater interaction of the university with the different social and productive sectors.

\section{The University Radio and Television System}

The first radio experiments date back to 1963, eleven years of projects and procedures carried out by engineers Jesús Cervantes Rangel and Alfredo Chavarría Velasco. On May 30, 1974, engineer José Río 
Madrigal and Ignacio Arriola Haro installed the first radio antenna of the University of Guadalajara in the gardens of the Technological Institute, currently the University Center of Exact Sciences and Engineering.

The first issue of "La Gaceta de la Universidad de Guadalajara" appeared on May 1, 1995, with the purpose of disseminating research, science, technology and culture. In the year 2000, the University of Guadalajara Radio Network was created within the state. The ninth station is significant for the inclusion of the Wixárika community of San Andrés Cohamiata, in the municipality of Mezquitic, Jalisco, part of the production will be produced by people from the community in their native language.

Since the creation of the University Network, the development of computing and telecommunications, the creation of the Library Network, and the incorporation of integral information and university administration systems (SIIAU) stand out.

In 2012, Channel 44 of university television began broadcasting. In 2018, two new channels were launched. In two Regional Centers, on January 31 in the south of Jalisco. On September 19, in Lagos de Moreno. The next one will be in Puerto Vallarta. The University Radio and Television System of the University of Guadalajara broadcasts diverse programs and disseminates cultural, artistic and scientific knowledge.

For example, the television series "De tequila hasta los huesos", a gift from the Gods of the pre-Hispanic world, in this program its history and cultural scope are explored; this television series is broadcasted on Channel 31.2 open television in Southern California, United States of America. Tequila, as well as mariachi and charros, represent the most valued and special traditions for Mexicans, tequila is present in any celebration and party; according to the riddle "never drink less than two and never more than three", the curious person when trying to solve it, ends up asking: "so, what was the tip?" (Arriaga Weiss \& Quintana Pali, 2017). It is consumed in more than 120 countries; the United States is the main country, followed by Germany, Spain, France and Brazil.

\section{Evaluation of Academic Programs}

In 2005, the accreditation process of the undergraduate academic programs, the change in the pension system and the implementation of the P3E System was born as an integral and online global process based on planning, budgeting and evaluation of the University Network.

In 2008, the reform of the general baccalaureate by competencies was approved and came into effect. According to the information SEMS has 174 campuses (55 metropolitan high schools, 44 regional high schools, 4 metropolitan modules and 91 regional modules and 7 regional extensions), in which 24 educational options are offered: the General Baccalaureate by Competencies, 22 educational options of technological baccalaureate and professional technologists and the General Baccalaureate by Interdisciplinary Areas. SEMS serves $53.39 \%$ of young people in the Guadalajara metropolitan area and $46.61 \%$ in regional schools. (CGPE, 2020). In addition, 94 private high schools are recognized by the U de G. Currently, $80 \%$ of high school students study in a certified school (see Table 2 ).

\section{SEMS SCHOOLS ON THE NATIONAL SYSTEM OF HIGHER SECONDARY EDUCATION'S GOOD QUALITY REGISTER}

\begin{tabular}{|l|l|l|}
\hline Level & School & Students \\
\hline 1 & 28 & 37,390 \\
\hline 2 & 86 & 59,433 \\
\hline 3 & 22 & 28,449 \\
\hline & 136 & 125,272 \\
\hline
\end{tabular}

Source: SEMS, 2021.

There are 144 undergraduate educational programs accredited by the Council for the Accreditation of Higher Education (COPAES); 27 with international accreditation; 31 evaluated at level I by the Inter- 
institutional Committees for the Evaluation of Higher Education (CIEES). In other words, 92.1\% of higher education enrollment corresponds to accredited programs.

On February 26, 2014, the Congress of the State of Jalisco declared the University of Guadalajara a Meritorious Member, in recognition "for the benefits it has provided in education to the State of Jalisco, in the field of scientific research for the benefit of humanity, as well as its contribution, trajectory and merits in teaching, its relevant contributions to education and training in the exercise of teaching" (Congress of the State of Jalisco, 2014).

The electronic portal of the University of Guadalajara under the acronym "udg.mx" of 20,300 universities, ranks 493rd in the world and 18th in Latin America and second in Mexico, according to the first report of this year made by the Superior Council of Scientific Research of the Government of Spain, (Carrillo Armenta, 2021).

The University of Guadalajara climbed 100 places in the University Impact Ranking 2021, going from position 201-300 to 101-200 of the best universities in the world. The ranking includes 1,117 universities from 94 countries, evaluated the fulfillment of the criteria: research, administration, dissemination and teaching according to the Sustainable Development Goals of the United Nations Organization (Madera, 2018).

As part of the fulfillment of public education policies, the Government of the State of Jalisco, through the Secretariat of Innovation, Science and Technology, promotes scientific research, technological development and innovation jointly with the link between the private, public, academic and social sectors, sharing the same goal and joining efforts to address the main problems with the use of technology to promote the economic and social development of the region.

The social service program and professional internships allow students to be linked to the workforce and favor their professionalization. They provide students with the opportunity to apply what they have learned, reaffirm their learning competencies, allow them to integrate into the labor sector and visualize possibilities of projecting themselves in a real environment.

The University-Government-Business and Society Partnership Program involves the university centers, seeks community benefit, contributes to the work of various sectors, maintains a close relationship with the surrounding communities, carries out actions of intervention with social responsibility, promotes actions for the environment and health through inter-institutional cooperation agreements, social and productive organizations.

The academic and cultural benefits established by the Regional Centers through transdisciplinary research applied to contribute to the solution of society's problems, regional sustainable development, address problems of sanitation of watersheds, needs of the public, social and private sectors, promote technological development for small and medium enterprises, establishment of business incubators and consulting, entrepreneurship, training, by participating in the Innovation Network for the Integral Development of the Regions.

The dynamics of regional development is generated from the integration of the social, productive and government sectors with the University of Guadalajara, cooperation allows to fulfill the mission of those who share common objectives in the formation and training of human resources, through inter-institutional agreements in strategic areas of medium and small business and local industry and environmental conservation among others.

Therefore, sustainable development aims to ensure that the impact of human activity does not harm the environment. Economic activity should be profitable in the long term with the adequate use of natural resources and that communities should be in harmony with their customs and traditions. Research should have defined the national and international contexts of the problem.

The academic offerings of the Regional University Centers are in accordance with the activities of each region, in addition to newly created careers. Their multidisciplinary orientation trains competitive students in the conservation and research of natural environments, as well as the rescue and dissemination of culture, science and technology through innovative undergraduate and graduate educational programs, contributing to sustainable regional socioeconomic development. The environment of the municipalities where they are present. 
In the particular case of the CUValles and CUNorte University Centers, they offer educational services in face-to-face and virtual contexts. In addition, the latter uses the B-Learning approach, adapting the educational programs to the reality of the bilingual Spanish-Wixárika environment.

These programs benefit society by preparing them with an entrepreneurial vision to start a business that can create jobs for future professionals, act as a monitor of change with innovative projects in their communities, participate in the training of food production, revaluation, rescue and analysis of their historical memory, promotion of physical activity and sports, and the promotion of the development of the community.

\section{CONCLUSIONS}

The University Network of Jalisco contributes to secondary and higher education; it expands and diversifies access in the different regions of the state. The General Administration coordinates the academic activities of the University Centers and Systems of the Network through the Council of Rectors, a planning body, whose functions are technical and advisory in updating the Institutional Development Plan.

The educational, cultural and economic impact that the University of Guadalajara has through the University Network in society, the development of the regions, has brought benefits to the inhabitants of Jalisco. It promotes scientific and technological research, as well as outreach and extension.

The social function of the university is the formation of the human being, it develops a direct connection with culture, ethics, social and political commitment. Since time immemorial, the University has been working with the communities, accompanying them in the development processes, transferring knowledge, and promoting the development of the communities.

The title of Meritorious University of Guadalajara is of special significance to the university community for its contributions to the socioeconomic and cultural development of the State of Jalisco and Mexico.

The coverage of TV Channel 44 with the creation of the Ibero-American scientific and cultural news program contributes to the dissemination and promotion of science, technology, innovation and culture in the Ibero-American region in 13 countries and 64 public entities: systems, associations, television channels and multimedia web platforms.

Consolidation of cultural promotion, such as the International Book Fair, the Julio Cortázar Latin American Chair and the International Film Festival in Guadalajara. In addition, in 2017 the Performing Arts Ensemble was inaugurated as part of the University Cultural Center.

We have fostered links and collaboration with the municipalities in the region, through agreements and participation in various municipal councils; strategies have been designed according to their particular needs. To promote innovation and development, we have a relationship with the business sector through collaborative projects to develop the entrepreneurial potential in the area.

We have promoted the linkage and collaboration with the municipalities of the region, through agreements we participate in various municipal councils; strategies have been designed according to their particular needs. To promote innovation and development, we have a relationship with the business sector through collaborative projects to develop the entrepreneurial potential in the area.

\section{ACKNOWLEDGEMENT}

Translated \& edited by American Publishing Services (https://americanpublishingservices.com/). 


\section{REFERENCES}

Arriaga Weiss, D., \& Quintana Pali, G. (2017). Mezcal, el elíxir de los Dioses. Retrieved from https://www.puertovallarta.net/espanol/ informacion-general/mezcal

Acosta Rico, F. (2016). El Espejo Histórico: Biblioteca Iberoamericana. Antiguo Colegio de Santo Tomás. Retrieved from http://www.cronicajalisco.com/ notas/2016/61563.html

Carrillo Armenta, J. (2021, June 10). Escala UdeG en el top 500 del ranking mundial de universidades en Internet. Universidad de Guadalajara. Retrieved from http://sems2.sems.udg.mx/sites/default /files/ boletin26.pdf

Castillo Girón, V.M., De León Arias, A., \& Ayala Ramírez, S. (2011). La Red Universitaria de Jalisco: Dispositivos de coordinación y vicisitudes de la interacción. Centro Universitario de Ciencias Económico Administrativas de la Universidad de Guadalajara. I Congreso Internacional de Educación Universitaria y Prácticas Educativas Innovadoras. Nezahualcóyotl, Estado de México, México Retrieved from http://adriandeleon.cucea.udg.mx/docs/RED_UNI_JAL.pdf

CGPE. (2020, December 31). Numeralia Institucional. Universidad de Guadalajara, Coordinación General de Planeación y Desarrollo Institucional. Retrieved from http://www.cgpe.udg.mx/sites/default/files/31_de_diciembre_2020_0.pdf

Congreso del Estado de Jalisco. (2014). La Benemérita Universidad de Guadalajara. Retrieved from http://www.udg.mx/es/benemerita

García Carmona, Ó. (2013). La educación preparatoria en Jalisco. In G. Hernández Obledo, Universidad de Guadalajara: Más de dos siglos de historia. Guadalajara, México. Editorial Universitaria/ Consorcio de Universidades Mexicanas.

Grandori, A., \& Soda, G. (1995). Interfirm Networks: Antecedents, Mechanism and Forms. Organization Studies, 16(2), 183-214.

Madera, G. (2021, May 18). UdeG sube 100 lugares en The University Impact Ranking 2021. Canal $44 y$ Radio UdeG Autlán. Retrieved from https://udgtv.com/noticias/udeg-sube-100-lugares-theuniversity-impact-ranking-2021/

Noticiasncc. (2019, November 21). Universidad de Guadalajara celebra 25 años de la Red Universitaria. Retrieved from https://noticiasncc.com/cartelera/articulos-o-noticias/11/21/universidadguadalajara-celebra-25-anos-red-universitaria/

Padilla López, J.T. (2006, February 6). Retos y Expectativas de las Universidades públicas en México: el caso de la Universidad de Guadalajara. Universidad Juárez del Estado de Durango.

Pérez García, I. S. Huerta Amezola, J. J. (n.d.). La Red Universitaria en Jalisco: una aproximación a los modelos académicos de los centros universitarios. Revista Educar, 6. Estrategias Cognitivas. Retrieved from http://www.quaderns digitals.net/datos_web/articles/educar/numero6/red.htm

PDI. (2014). Plan de Desarrollo Institucional 2014-2030. Construyendo el futuro. Universidad de Guadalajara. Pandora. Retrieved from http://www.udg.mx/sites/default/files/ adjuntos/pdi-udg2014-2030_v4.pdf

Real Ledezma, J. (2015). La historia de la Universidad de Guadalajara. Retrieved from http://www.udg.mx/es/historia

SEMS. (2015). Plan de Desarrollo 2014 a 2030. Universidad de Guadalajara, Sistema de Educación Media Superior. Retrieved from http://sems.udg.mx/sites/default/ files/pdsems_20142030_version_final_digital.pdf

SEMS. (2021). Planteles del SEMS pertenecientes al PC-SINEMS. Sistema de Educación Media Superior. Retrieved from https://www.sems.udg.mx/planteles-del-sems-pertenecientes-al-pcsinems

Solís Gadea, H.R. (2013). Una Universidad en proceso de reforma 1989-1995. In G. Hernández Obledo, Universidad de Guadalajara: Más de dos siglos de Historia, (pp. 331-344). Guadalajara, México. Editorial Universitaria/ Consorcio de Universidades Mexicanas.

UdeG. (1991). Reforma Universitaria. Reglamento para los foros de análisis y discusión de la Reforma Académica en la Universidad de Guadalajara. México: Universidad de Guadalajara.

172 Journal of Higher Education Theory and Practice Vol. 21(15) 2021 
UdeG. (2014A). Acto de Conmemoración XX Aniversario de la Red Universitaria. Retrieved from http://www.udg.mx/sites/default/files/adjuntos/folleto_xxaniv_red_universitaria_udg_20141112.p df

UdeG. (2014B). Folleto conmemorativo por el XX aniversario de la Red Universitaria.

UdeG. (2014C). Red Universitaria de Jalisco. Institución Benemérita de Jalisco. Retrieved from http://www.udg.mx/sites/default/files/adjuntos/folleto_institucional_udg2014.pdf

UdeG. (2018). ¿Qué es la Red Universitaria? Sitio desarrollado por Coordinación General de Tecnologías de Información. Retrieved from http://www.udg.mx/es/info/ preguntas/qu-es-la-reduniversitaria

UdeG. (2018, February 8). Informe de actividades 2017. Universidad de Guadalajara. Jalisco, México, p.10. Retrieved from http://www.rectoria.udg.mx/sites/default/ files/ia2017-mensajetbp.pdf

UdeG. (2019). 25 años de la Red universitaria. Universidad de Guadalajara. Retrieved from http://25aniversariored.udg.mx/

UdeG. (2020, May 20). Anuncian sede en Tlajomulco para la Universidad de Guadalajara. Gaceta. Retrieved from http://www.gaceta.udg.mx/anuncian-sede-en-tlajomulco-para-la-universidad-deguadalajara/

UPZMG. (2018). Plan Institucional de Desarrollo 2014-2018 de la Universidad Politécnica de la Zona Metropolitana de Guadalajara. Retrieved from https://seplan.app. jalisco.gob.mx

Villarruel Alvarado, E. (2014, November 12). V. La Red Universitaria de Jalisco, 1989 - actualidad en Folleto conmemorativo por el XX aniversario de la Red Universitaria. Retrieved from http://www.udg.mx/nuestra/presentacion/historia/pe riodos/periodo-v 